\title{
The Use of Sectarian Ties Inside Syrian Modern Political System
}

\author{
Valentina Zecca \\ University of Calabria, Cosenza, Italy
}

\begin{abstract}
This article explores the concept of sects as social formations and the process of secularization sects has been undergone in the modern era, implying their exposition to political manipulation by various internal and external actors. We analyse this subject in the context of the modern Syrian State and, in particular, with reference to the political system established by President Hafez al-Asad in the 70's. The use of sectarian ties appears as part of the regime patrimonial features, being a political strategy used in order to bind particular society's groups to the regime. In this sense, sectarianism has nothing to do with religion and it requires to be analysed as a socio-political phenomenon. This kind of analysis permits also to confute the identification between the Asad regime and the Alawite community and to understand the complexity of the relation between the President and the community he originated from.
\end{abstract}

Keywords: Syria, sectarianism, Hafez al-Asad, patronage, national state

\section{Introduction}

Talking about sectarianism in Syria requires some necessary premises because at a first look it may appear as something very different from what it actually is. Indeed, sectarianism in the Middle East is usually perceived as a problem related to religion, implying in this way a judgement about the incapacity of Middle Eastern societies to separate the religious from the political sphere. U. Maqdisi (2000; 2008), along with other scholars who have recently explored the topic of sectarianism ${ }^{1}$, argues, on the contrary, that, owing to the process of secularization they have undergone, sects should be read as social realities that changed throughout history. It has become rather evident that the current problems related to sectarian violence are rooted in the modern socio-political system and that the religious, as well as the ethnic, differences that characterize Middle Eastern societies are not the cause of the conflicts emerged in past decades or in recent years.

In his article titled "Secular Sectarians", Fanar Haddad notices that sectarianism it is not a confrontation upon doctrinal problems, neither it has to do with the imposition of a certain doctrine over others. He also connects the term "secular" to "sectarian" because of the secular or political reasons which have subtended the sectarian dynamics in Iraq and Syria since 2003. He states that "the most consistently overlooked aspect of modern sectarian relations in the Arab world is that they are far more rooted in contests over national rather than religious truths" (Haddad, 2014).

Valentina Zecca, Research Fellow, Department of Languages and Educational Sciences (LISE), University of Calabria.

1 See for instance: Philips, C. (2015); Brubaker, R., Loveman, M., and Stamatov, P. (2005); Peteet (2008); Joseph (2008).

${ }^{2}$ Haddad's article is part of a debate titled Sectarianism in Middle East and Asia appeared on the Middle East Institute's website: http://www.mei.edu/content/sectarianism-middle-east-and-asia. 
Mohammad Dibo, contributing to a debate regarding sectarianism in Syria ${ }^{3}$ with an article titled "Asad's Secular Sectarianism", stresses how the "manipulation of sectarianism was one of the methods used by the Syrian regime to preserve its control over decades" (Dibo, 2014).

Whether sectarianism finds its explanation in the way groups struggle for power and control over the national State's resources or whether it is tied to the way one group manipulates sectarian or other identitarian ties in order to maintain power and control over the State, how should we consider the role of sectarian ties inside the modern Syrian political system?

\section{Sects in Syrian Modern State}

The first episodes of sectarianism, in Arabic tạ ifiyya ${ }^{4}$, appear in the Middle East at the end of the 19th century when inter-communitarian violence exploded in Mount Lebanon, and extended then in Damascus, between Christian and Druze/Muslim communities. In such a context, the word ța 'ifa ("sect" or "confessional community"5) was reshaping its meaning, incorporating a political significance that was not part of its original connotations. This was the reflection of a process of social transformation which interested the populations subjected to the Ottoman Empire during the 19th century, a period in which the modernization of the Empire involved a new definition of citizenship influenced by the European thought and its political interference. As Maqdisi (2000) affirms, it was a period in which each community of the Levantine provinces of the Empire was undergoing a reshaping of its political self-definition along religious lines in a process that had given birth to a new cultural, political, and geographic conformation where: "a kind of religious identity is politicized, even secularized, as part of an obvious struggle for power" (Maqdisi, 2008, p. 559). This new conformation was fully developed with the creation of the Lebanese State, in which the sectarian representation became the base of the national political system.

In the same period, another concept, strictly connected to tā 'ifa, developed, the concept of minority, which emerged when the existence of numerically inferior cultural defined groups became politically meaningful (White, 2007). As B. White highlights, the concept of minority implies philosophical and geographical preconditions associated with the modern State: the former is tied to the emergence of a representative government, the latter is related to State territorial boundaries and to the extension of the State's authority over the heterogeneous population its borders contain. The creation of minorities is linked to the concept of legitimacy because of a cultural link, the national identity, used by the ruler to legitimate his claim to represent the population subjected to the State's authority. Given this national/cultural identity defining a "majority", the cultural-defined groups falling outside this definition, but inside the State geographical borders, become minorities (White, 2007, pp. 66-67).

The concept of sectarianism (țä ifiyya) in the Middle East emerges along with the concepts of nation, majority, and minorities, which started to be at the base of the socio-political organization of the region. As for the notion of minority, it comes in as a new political value attributed to a cultural/religious identity explaining the existence of sects and sectarianism inside the political game. In other words, it is the creation of sects as a

3 The debate was published between 2014 and 2015 on the website opendemocracy.net: https://www.opendemocracy.net/freeform-tags/syria-and-sectarianism.

${ }^{4}$ Derived from the word ța 'ifa, that refers to a confessional community. The term ța 'ifiyya has a modern origin that is linked to the political system created by the French power in the Levantine provinces under its mandate and fully developed in Lebanon after the independence (Bayḍūn, 2012).

${ }^{5}$ It refers to a community or a group with a particular religious or doctrinal belief. 
secular formation which explains their political significance within the functioning of the national political system.

For what concerns the Syrian State in particular, the definition and self-definition of communities along religious lines which started in the 19th century, was pushed into its full expression during the Mandatory period. The French authority, that was legitimating its presence through a speech focused on the protection of minorities, created, inside the artificial Syrian boundaries, two new entities defined by a confessional identity, marking the birth of the two small Alawite and Druze States (1922) established in two regions of the modern Syrian State where people belonging to Alawite and Druze faith ${ }^{6}$ represented the majority of the population.

The creation of these new territorial and political realities is part of the process of transformation of religious and ethnic communities into secular formations which were then competing in the political arena of new modern States. The manipulation made by the French Mandatory power upon religious identities found its expression also in the distribution of parliament's seats along sectarian bases and in the changes made on the juridical status of some confessional communities (belonging to heterodox Islam) which were entitled to a separated juridical status never known before. This was a clear contradiction of the French policy in the States under its mandate: it was supposed to be there to support a process of secularization of the political system but in reality it was fostering a systematization of the political role of religions. In doing so, it was hampering the possibility of secularization of both the juridical and administrative systems.

Alawite and Druze States were assimilated to the Syrian one with the Independence (1946) and the integration of the Syrian territory was a great challenge for the government of the new State, especially with regards to the socio-economic gap among the different regions and the deep cleavage between the rural and the urban background.

With regard to the sectarian setting of the political context, Syria followed a completely different path from Lebanon. During the decades following the Independence, the Syrian political scenario had been progressively changing due to the weakness and incapacity of the elite governing the country, the transformation of the Syrian society, and the birth of new vectors of socio-political change. First of all, in this period new political parties were established based on nationalist but also radical and progressive ideologies. Furthermore, the Army was acquiring a growing important role inside the political sphere. In the period between 1949 and 1954, which is known in the Syrian history for the succession of numerous coups, the sectarian representation of the government was progressively abolished in a process culminated in 1953, during the government of Colonel Shishakly.

The new radical parties together with the Army represented the two main vectors of political change in Syria after the Independence. They were also vectors of social change and integration of peripheral and rural regions into the State apparatus. And, because of the minoritarian composition of some Syrian peripheral and rural regions ${ }^{7}$, they represented also the vector of integration of elements coming from a minoritarian background inside a State apparatus which was traditionally dominated by urban and Sunni notables.

The Syrian Social Nationalist Party of Antoun Sa'adeh, the League of National Action of Zaki al Arsuzi, the Arab Socialist Party of Akram al Hawrani, the Communist Party and the Ba'th were the new political forces affirming themselves in this period. Each of them adopted a different model of nationalism, but they all

\footnotetext{
${ }^{6}$ As heterodox currents of Islam, people belonging to this faith have been sometimes persecuted by traditional Sunni authorities but they didn't have a separated juridical or political status during the Ottoman Empire.

7 The so-called compact minorities in Syria (see Rabinovich, 1979): a term which refers to the presence of minoritarian communities that forms a majority in certain regions of the Syrian territories (like the coastal zone for the Alawites and the southern region for the Druze).
} 
fostered a radical change in the political system and a renewal of the Syrian society. Their ideological references were heterogeneous but they all shared a secular inspiration and were able to attract followers from both the rural and the middle class environments and from the Sunni and the various ethnic and confessional minorities. The Ba'th party had a secular and socialist ideology and aimed to a great Arab nation in which there was no space for any reference to confessional or ethnic minoritarian identities.

As for the role played by the national Army, it was the heir of the Special Troupes of the Mandatory period, which had recruited elements coming from a minoritarian background because they were less influenced by nationalist ideologies. In addition to this, the Army had a strong percentage of members coming from the rural background due to the fact that the Army was a mean of upward mobility for the young men of rural origins while the urban Sunnis were used to pay money to avoid the military service.

When the Ba'th party took power in 1963, its coup represented a deep change in the history of the Syrian State. First of all, it meant a shift from the conservative parties which had ruled until that time, whose members came from the rich families of notables and landowners, to a progressive party representing the middle class and the peasants. But it also determined a change in the composition of the elite because the new rulers belonged to the Army and were of minoritarian origin coming from peripheral and rural areas. Inside the Military Committee under the Ba'th, active in the coup later known as the Ba'thist revolution of 8th March 1963, the percentage of elements belonging to the Alawite, Druze, and Ismaili communities was very high. These members would later struggle together with other components of the military coalition leading the coup and with other currents of the Ba'th party, in order to obtain the full power within the Syrian State.

\section{The Use of Sectarian Ties Inside Hafez al Asad Political System}

The period between 1963 and 1970 in Syria was characterized by a struggle for power among different factions of the Army. The Ba'th party took power in a very sensitive period of its history, when it was both regionally and ideologically fragmented in many different factions, split into a military and a civil wing and without a strong leadership.

In a time in which coups were frequent, to have a firm control of the military institution was considered strategic and very important for maintaining power. For this reason the Army became the arena of an elite struggle characterized by an extreme factionalism and the lack of a strong leadership.

In this context, the leaders of each faction were trying to gain a support as larger as possible, resorting to every kind of loyalty they could mobilize, manipulating different ties (personal, generational, class, regional, and sectarian) to widen their support base or to compact their followers. This strategy of mobilization of personal, regional, and sectarian ties was adopted by the competing leaders also to purge enemies ${ }^{8}$. This did not mean that the factions or the political conflicts were expressing a struggle between sectarian or regional blocs: the rival coalitions represented a multitude of actors and their composition was fluid, changing according to the different circumstances.

The last coup of the Syrian history, led by General Hafez al-Asad in 1970, established the supremacy of a faction which took the most important seats of the State: the Regional Committee of the Ba'th party, in its military and civil wings, and governmental high ministers. Within this elite, the Alawite component and the region of Latakia were overrepresented in comparison with the general composition of the Syrian society

\footnotetext{
${ }^{8}$ About the use of sectarian ties in the period 1963-1970, see: Van Dam (1978; 1996), Batatu (1999), Rabinovich (1972), Hinnebusch (1990).
} 
(Drysdale, 1981; Van Dam, 1978; 1996). But these numbers can be explained by the high percentage in the Army of elements coming from peripheral, rural, and minoritarian backgrounds and by the dynamics of manipulation of personal-regional-sectarian ties implemented during the intra-elite struggle for power. What kind of role sectarian ties have exercised inside the political system established by Hafez al-Asad? Did the Alawite origin of President Asad, play a role within his political regime? We will try to answer these questions in the paragraphs below.

It is known that in Syria, after 1970, every sectarian reference was a taboo because it undermined the ideology of the Ba'th party that was one pillar of Hafez al-Asad's system of power. Furthermore, Asad's policies were not aimed at sectarian goals, as many scholars of Syrian politics recognize (see for instance Le Gac, 1991; Batatu, 1999). Many scholars underline also the false association between the Asad regime and the community he originated from (Balanche, 2006; Perthes, 1995). It has no sense to talk about an Alawite regime or the capture of power by the Alawite community over the Syrian State. What should be investigated concerning the role of sectarian ties within the political system, is the modality of manipulation of sectarian ties by political actors. With regard to President Asad, we can assume that he used sectarian ties to consolidate and to maintain his power: during his struggle for power he probably resorted to sectarian ties in order to fill the ranks of his followers ${ }^{9}$, while during the phase of consolidation of his power, sectarian ties were used to expand the network of patronage which characterized the functioning of his political system.

We consider Hafez al-Asad's regime an authoritarian regime that had reached a certain degree of institutionalization, maintaining at the same time an important patrimonial core (Hinnebusch, 1990; Perthes, 1995).

The patrimonial core of the regime was represented by a group of militaries in charge of the highest offices of the Syrian State (government, army, Regional Committee of the Ba'th party). This group is defined by some scholars as jamā'at al-Asad, the Asad group or clique, a group of people that had a personal tie with President Asad (Ma’oz, 1986; Donati, 2009; Kienle, 1991).

We cannot thus talk of an Alawite core, led by a sectarian logic, also because it was composed by elements coming from different communitarian backgrounds (such as Sunni) ${ }^{10}$. The crucial factor which cemented this group was the personal relationship or closeness to the President. Every strategic position, and in particular those related to the regime security, were held by a person with a strong personal relationship with the President. This is true for members of the Asad's family, clan, or community, as well as for Sunni members who obtained a ministerial office. In this group or jamā 'a, every person was there because of Asad's will and was tied to him by an absolute loyalty ${ }^{11}$ (Kienle, 1991, p. 213).

\footnotetext{
9 This is what Van Dam (1996) assumes, quoting the testimonies of some members of the Ba'th party.

10 The presence of Sunni elements inside the government is sometimes explained as a formality made to please the Sunni community, assuming that those people do not have a real power. On the contrary, Perthes assumes that: "..Sunni members of the President's inner circle [...] have not obtained their positions as alibi-Sunni or in order to please the Sunni majority. Nor do Asad's strongmen hold their positions because they are Alawis. They are all there because they have been Asad's friends, comrades, and loyal followers for a long time" (Perthes, 1995, p. 182). About this aspect see further below.

${ }_{11}$ The kind of loyalty which ties jama'a-t al-Asad, is defined by many authors with the concept, elaborated by Ibn Khaldun, of 'așabiyya (Seurat, 2012; Balanche, 2006; Ma'oz, 1986; Donati, 2009; Kienle, 1991). Translated as "esprit de corps, group feeling", 'așabiyya is defined by O. Roy (2004) as a solidarity group (groupe de solidarité) based upon personal relations (genealogical, matrimonial, clientelistic, communitarian, and so on) (Roy, 2004, p. 44). According to Kienle, the 'așabiyya is constituted at the intersection among different social cleavages. In the Syrian regime, the așabiyya was built through family, tribal, confessional ties but was also based upon a common life experience or different parameters as the rural origin or the belonging to the army or the Ba'th party (Kienle, 1991, p. 214).
} 
This patrimonial core was at the top of a patronage network which, departing from State's institutions, reached every level of the Syrian society (Donati, 2009; Picard, 1996). As Perthes highlights, the authoritarian nature of political behaviours attributes great importance to patronage networks because they have a particular role inside the Bureaucracy or State sectors, Party apparatus and popular organizations: they must regulate the inclusion inside State's structures and be a useful mean of control. As Perthes (1995, p. 181) states: "Access to resources, be they services, employment, licenses, other material or non-material benefits, or political influence, often needs wasta [mediation], and wasta is best obtained through vertical patronage networks as well as through less hierarchical family relationships and regional or ethnic ties which, of course, often form the very lines along which patron-client relations are knit. Patronage, as a technique or power, is based on the exchange of resources, or access to them, for loyalty or obedience".

So through patronage, which often — but not always - is based on and manipulates regional, sectarian, or communitarian ties, the regime was able to win the backing of strategic groups as the militaries or part of the bourgeoisie. It also helped raise support for the regime by groups that otherwise would have never been regime supporters.

This dynamic of patronage also explains Asad's relationship with his community of origin. The Alawite community was not supporting the regime by virtue of his communitarian belonging. As Balanches explains, the communitarian belonging is a social tie which could be potentially mobilized but which is not automatic. In order to obtain a support base inside the Alawite community, Asad had to use a patronage strategy: loyalty in change of material benefits (Balanche, 2006, p. 171). According to this author, the power of Asad's network marginalised other Alawite networks and the power of traditional community representatives ${ }^{12}$. By exercising control over the State's apparatus and resources, Asad reached an exceptional political and economic power (Balanche 2006, pp. 196-197). The kind of assistance the regime granted in a preferential way to the Alawites (for instance the allocation of bank loans or employment in the state sectors) allowed establishing the dependence of some Alawites from the regime and to ensure an Alawite client base to Asad from which his trusted staff and in particular his Praetorian Guard were hired (Balanche, 2006, pp. 169-171). Nevertheless, this privileged channel through which many Alawites got access to public employment and their massif recruitment inside the repressive state apparatus (the Army and the intelligence) ${ }^{13}$, has stimulated an identification between the Alawite community and the regime with disastrous consequences in the generation of sectarian speeches and violences.

\section{Sectarian Speeches and Violence}

We saw above that sects have changed during the modern era, through a process of secularization by which they acquired a political value, where political actors have engaged in the manipulation of sectarian (or identitarian/cultural) ties, within a mechanism defined by the term tā ifizya.

During the course of Syrian history, this kind of manipulation has been exercised by various actors: the Mandatory and foreign powers which leveraged sects looking for legitimization to intervene in Syrian politics;

\footnotetext{
12 Also Le Gac underlines that the relationship between Asad and the Alawite community is not a traditional relation but a form of political patronage, so that he notices the presence in the Alawite region of "personal clans", tied to some important regime figures (Le Gac, 1991, pp. 80-81).

${ }_{13}$ Michel Seurat, analyzing the recruitment of Alawites inside the security apparatus, assumes that Asad's politics aimed at tying the destiny of the Alawi community to his own destiny, making the Alawites a glacis de protection of his regime (Seurat, 2012, $\mathrm{p}$. 64).
} 
local political actors, who used sectarianism for their short-term goals, such as consolidating their power or obtaining the support of certain groups.

Sectarianism in Syria was not - except for a short period - part of the state political organization as it is in Lebanon. However, although not publicly visible, it entered some mechanisms of the political game, we refer, in particular, to the patrimonial and patronage methods of the governing regime.

Hafez al-Asad regime has been often accused of sectarianism. Sometimes, as in the 70's-80's crisis, the criticism against the regime took a confessional form, creating a sectarian polarization of the society which engendered sectarian violence and led to the murder of regime personalities belonging to the Alawite community. For his part, the regime accused the opposition to be sectarian and presented himself as the only authority able to guarantee secularism and the protection of the country's minorities. The same circumstances and speeches were used during the current crisis, in which the regime as well as the oppositions has mutually accused the other side of sectarianism.

We are not interested here in judging the behaviour of the regime or the oppositions, but it is necessary to emphasize how sectarianism ( țā 'ifiyya) is, beyond a socio-political practise, also a narrative used by various actors in order to discredit the adversaries. Sectarianism is a speech which can engender violence and fear toward the other. The identification between the Alawite community and the elite in power is, without any doubt, not correct and was exploited by the regime and by certain opposition with the result that it has generated terrible violence against civilians. In the current context, sectarianism cannot be considered as a cause of the crisis neither the Syrian territory's partition upon sectarian bases can be considered a solution to the conflict. On the contrary, a sectarian division could only generate more violence and a higher confusion in relation to the political organization of the country. It could also become the perfect pretext for foreign powers to enter Syrian politics. So it is of great importance to shade a light upon the manipulation of sectarian ties made by different political actors and to suggest that Syrian politics could find its definition away from sectarian speeches and practises, which unfortunately have already infiltrated the political game but could still be resisted

\section{References}

Balanche, F. (2006). La région alaouite et le pouvoir syrien (The Alawite region and the Syrian power). Paris: Karthala.

Batatu, H. (1999). Syria's peasantry: The descendants of its lesser rural notables and their politics. Princeton: Princeton University Press.

Bayḍūn, A. (2012). Mușțalā țā’ifa wa țâ’ifiyya. Tarsīmun li-nasabihimā al-dalālī 'alā niyya al-mutarjimīn (The terms țā'ifa and țā'ifiyya. The description of the relation between them and between the purpose of the translators). Bidāyyāt, 3-4, $206-212$.

Brubaker, R., Loveman, M., \& Stamatov, P. (2005). Ethnicity as cognition. Los Angeles: University of California.

Chouet, A. (1995). L'espace tribal alaouite à l'épreuve du pouvoir (The Alawite tribal space to the test of power). Maghreb-Machrek, 147, 83-119.

Dibo, M. (2014). Asad's secular $\quad$ sectarianism. $\quad$ Retrieved from https://www.opendemocracy.net/freeform-tags/syria-and-sectarianism

Donati, C. (2009). L'exception syrienne. Entre modernisation et résistance (The Syrian Exception. Between modernization and resistance). Paris: La Découverte.

Drysdale, A. (1981). The Syrian political elite 1966-1976: A spatial and social analysis. Middle Eastern Studies, 17(1), 3-30.

Haddad, F. (2014). Secular sectarians. In Sectarianism in Middle East and Asia, Middle East Institute, http://www.mei.edu/content/sectarianism-middle-east-and-asia

Hinnebusch, R. (1990). Authoritarian power and state formation in ba'thist Syria: Army, party and peasant. Boulder: West-View Press. 
Joseph, S. (2008). Sectarianism as imagined sociological concept and as imagined social formation. International Journal of Middle East Studies, 40, 553-554.

Kienle, E. (1991). Entre jama'a et classe: le pouvoir politique en Syrie contemporaine (Between jama'a and class: The political power in contemporary Syria). REMMM, 59(59-60), 211-239.

Le Gac, P. (1991). La Syrie du general Assad (General Asad's Syria). Bruxelles: Éditions Complexe.

Ma‘oz, M. (1986). The emergerce of modern Syria. In M. Ma'oz \& A. Yaniv (Eds.), Syria under Asad: Domestic constraints and regional risks (pp. 9-35). London: Croom Helm.

Maqdisi, U. (2000). The culture of sectarianism: Community, history and violence in nineteenth century Ottoman Lebanon. California: University of California Press.

Maqdisi, U. (2008). Moving beyond orientalist fantasy, sectarian polemic and nationalist denial. International Journal of Middle East Studies, 40, 559-560.

Perthes, V. (1995). The political economy of Syria under Assad. London: I.B. Tauris, London.

Peteet, J. (2008). How useful has the concept of sectarianism been for understanding the history, society and politics of the Middle East? International Journal of Middle East Studies, 40, 550-552.

Philips, C. (2015). Sectarianism and conflict in Syria. Third World Quarterly, 36(2), 357-376.

Picard, E. (1996). Fin de partis en Syrie (The end of political parties in Syria). REMMM, 81-82, 207- 229.

Rabinovich, I. (1972). Syria under the Ba'th, 1963-66: The army-party symbiosis. Jerusalem: Israel Universities Press.

Rabinovich, I. (1979). The compact minorities and the Syrian state, 1918-1945. Journal of Contemporary History, 14(4), 693-712.

Roy, O. (2004). Groupes de solidarité, territoires, réseaux et État dans le Moyen-Orient et l'Asie Centrale (Solidarity groups, territories, networks and State in Middle East and Central Asia). In H. Dawod (Ed.), Tribus et pouvoirs en terre d'Islam (Tribes and power in the land of Islam). Paris: Armand Colin.

Seurat, M. (2012). L'État de barbarie (The State of barbarity). Paris: Presse Universitaire de France.

Van Dam, N. (1978). Sectarian and regional factionalism in the Syrian political élite. Middle East Journal, 32(2), 201-210.

Van Dam, N. (1996). The struggle for power in Syria. London: I.B. Tauris.

White, B. (2007). The Nation-State Form and the emergence of "Minorities" in Syria. Studies in Ethnicity and Nationalism, 7(1), 64-85. 